\title{
Printing of cotton fabric with Catechu bark
}

\author{
MAMTA AGRAWAL, SAROJ S. JEET SINGH AND N.M. ROSE
}

Received: 23.10.2017; Revised: 11.11.2017; Accepted: 26.11.2017

See end of the paper for authors' affiliations

\section{MAMTA AGRAWAL}

Department of Textile And Apparel Designing, I. C. college of Home

Science, Chaudhary Charan Singh Haryana Agricultural University,

HISAR (HARYANA) INDIA
ABSTRACT : The study was to explore the printing of cotton fabric with natural dyes extracted from catechu bark. The printing receipe was standardized using different variables viz., extraction $\mathrm{pH}$, dye paste, $\mathrm{pH}$ of guar paste, dye paste and guar paste ratio, fixer concentration and mordant concentration. Copper sulphate and ferrous sulphate were used as mordants and colour fastness properties of printed samples were evaluated. The results indicated that different shades of brown and black were obtained using mordants with excellent washing and sunlight fastness. It was observed that washing made colour brighter and faster.

KEY WORDS: Printing, Cotton fabric, Catechu bark

- HOW TO CITE THIS PAPER : Agrawal, Mamta, Singh, Saroj S. Jeet and Rose, N.M. (2017). Printing of cotton fabric with Catechu bark. Asian J. Home Sci., 12 (2) : 627-630, DOI: 10.15740/HAS/AJHS/12.2/ 627-630. 